\title{
Experimental Evaluation of the Penalty Associated With Micro-Blowing for Reducing Skin Friction
}

Danny P. Hwang and Tom J. Biesiadny

Lewis Research Center, Cleveland, Ohio

Prepared for the

36th Aerospace Science Meeting and Exhibit

sponsored by the American Institute of Aeronautics and Astronautics

Reno, Nevada, January 12-15, 1998

National Aeronautics and

Space Administration

Lewis Research Center 
Available from

NASA Center for Aerospace Information 800 Elkridge Landing Road

Linthicum Heights, MD 21090-2934

Price Code: A03
National Technical Information Service 5287 Port Royal Road Springfield, VA 22100 Price Code: A03 


\title{
EXPERIMENTAL EVALUATION OF PENALTY ASSOCIATED WITH MICRO-BLOWING FOR REDUCING SKIN FRICTION
}

\author{
Danny P. Hwang and Tom J. Biesiadny \\ National Aeronautics and Space Administration \\ Lewis Research Center \\ Cleveland, Ohio 44135
}

\begin{abstract}
A micro-blowing technique (MBT) experiment was conducted in the Advanced Nozzle and Engine Components Test Facility ${ }^{1}$ at the NASA Lewis Research Center. The objectives of the test were to evaluate the pressure-drag penalty associated with the MBT and to provide additional information about the porous plates used for micro-blowing. The results showed that 1 of 12 plates tested could reduce the total drag (skin-friction drag plus pressure drag) below a solid flat plate value. The results of this experiment and prior data showed that atotal drag reduction below a solid flat plate value was possible. More tests are needed to find an optimal MBT skin and to find a technique to reduce pressure drag.
\end{abstract}

\section{Symbols}

$A_{a} \quad$ surface area of airfoil

$A_{s} \quad$ total surface area of two test plates

$C_{d} \quad$ drag coefficient, (total drag force $) /\left(1 / 2 \rho_{\infty} u_{\infty}^{2} A_{a}\right)$

$C_{d 0} \quad$ drag coefficient of solid flat plate

$C_{d w 0}$ drag coefficient of porous plate without blowing

$F \quad$ blowing fraction, $\left(\rho_{b} v_{b}\right) /\left(\rho_{\infty} u_{\infty}\right)$

$\mathrm{Re} / \mathrm{m}$ Reynolds number per meter

$\rho_{b} \quad$ blowing air density

$v_{b} \quad$ average blowing air velocity

$\rho_{\infty} \quad$ free stream density

$u_{\infty} \quad$ free stream velocity

Introduction

A proof of concept experiment (phase I) for reducing skin friction, using the micro-blowing technique, was tested in July and August, 1995 in the Advanced Nozzle

This paper is declared a work of the U.S. Government and is not subject to copyright protection in the United States. and Engine Components Test Facility ${ }^{1}$ at the NASA Lewis Research Center. The test results were reported in Ref. 2. The results from phase I showed that the MBT could reduce skin friction significantly for subsonic flow, especially for flow with a low Reynolds number.

In order to assess the pressure-drag penalty associated with the MBT, an assessment experiment (phase II) was conducted in the same test facility in August through November, 1996. Test plates were installed on both sides of a constant thickness airfoil. The airfoil was mounted on a balance so that the total drag, pressure drag, and skinfriction drag, could be measured directly. The Mach numbers tested were from 0.35 to $0.7\left(\mathrm{Re} / \mathrm{m}=1.96(10)^{6}\right.$ to $\left.4.23(10)^{6}\right)$ and the exit pressure of the wind tunnel was set at a constant pressure of $0.24 \mathrm{~atm}$ (corresponding to $10.7 \mathrm{~km}$ altitude). The experiment results are presented herein.

\section{Test Model}

A constant thickness airfoil, with the thickness of $2.03 \mathrm{~cm}$, height of $13.7 \mathrm{~cm}$, and length of $45.72 \mathrm{~cm}$, was designed using the NPARC Navier-Stokes code ${ }^{3}$ so that the flow was not separated at a Mach number of 0.7 . Tufts were used for flow visualization at Mach 0.7 to ensure that the flow remained attached. The airfoil was vertically installed on the top of a balance and a gap of $0.2 \mathrm{~mm}$ between the airfoil and the tunnel floor was carefully checked before the test. Figure 1 is a sketch showing the plate on the airfoil. In this figure, the front and the top wall of the wind tunnel are removed for a clear view of the test plate and the airfoil. The rectangular porous plates are 12.36 by $25.06 \mathrm{~cm}$ and were installed on both sides of the flat section of the airfoil, $5.08 \mathrm{~cm}$ from the leading edge (Fig. 1). The location of the plates was in the constant pressure region for most of the flow conditions.

\section{Plates Tested}

The test plates were constructed of two layers. For all the plates, the inner layer was a 30-microns, high-density, polyethylene porous plate, which was glued to the outer layer around the edge of the plate. The outer layers tested are listed in Table I. Most of the outer layers were provided 
by Northrop Grumman Corporation. The LARC1 plate was provided by NASA Langley Research Center. It was laser drilled and the shape of the hole was irregular.

The test plates used in this experiment were slightly different from the test plates used in phase $I$. The phase $I$ plates had a gap of $0.762 \mathrm{~mm}$ between the outer layer and the inner layer; however, based on the test results from Walkinson ${ }^{4}$, we speculated that more skin-friction reduction could have been achieved in the phase $I$ test if there were no gap between the two layers. Therefore, there was no gap for the phase II test plates as shown in Fig. 2. Moreover, the thickness of the phase II inner layer was $3.175 \mathrm{~mm}$ instead of the $9.14 \mathrm{~mm}$ used for the phase I test plates.

\section{$\underline{\text { Test Facility }}$}

The Advanced Nozzle and Engine Components Test Facility' was modified for this experiment. A constant rectangular cross-section duct $(20.32-\mathrm{cm}$ wide, $14.22-\mathrm{cm}$ high, and 76.2-cm long) replaced the usual test article. A $12.7-\mathrm{cm}$-long transition duct was used to connect the test section to the facility.

\section{Instrumentation}

Figure 3 shows the experiment setup and the locations of the balance and the test model. A load cell with a maximum capacity of 4536 grams was used. The accuracy of the load cell, based on the manufacturer's specification, was \pm 0.25 percent. There was an opening on the tunnel floor in the shape of the airfoil. Because the airfoil cannot touch the tunnel floor, there was a small gap of $0.2 \mathrm{~mm}$ between them. Sixteen Pitot static tubes were installed at a location $2.54 \mathrm{~cm}$ from the exit plane, as shown in Fig. 1 . Because there were not enough rakes inside the wake of the airfoil and the measurements were unsteady, the data from these rakes were not usable. There was a total pressure tube, a thermocouple, and a static pressure tap installed on the side wall for measurement of the freestream Mach number at the leading edge of the test plates.

A 1500-standard-liter/min (SLM) flowmeter was used to measure the flow rate of blowing air.

\section{Calibration}

The internal load cell shown in Fig. 4 was used to measure the total force $\left(F_{\mathrm{drag}}\right)$ on the airfoil. The indicated force from this load cell, however, is reduced by the friction force of the balance support and bearings as

$$
F_{\text {indicated }}=F_{\text {drag }}-F_{\text {fric }}
$$

In order to estimate the magnitude of the friction force, a calibration load $\left(F_{\text {calib }}\right)$ was applied to the balance through an identical, external reference load cell. The external load cell was connected to the balance with a straight lightweight rod that was removed after calibration. The calibration was performed with no wind tunnel flow. The actual load on the balance (either $F_{\text {drag }}$ or $F_{\text {calib }}$ ) is equal to the indicated load (internal cell) plus the friction load

$$
F_{\text {actual }}=F_{\text {indicared }}+F_{\text {fric }}
$$

The internal load cell was calibrated for all test plates. A typical calibration curve is shown in Fig. 5. The calibration curve is linear and passes through the origin.

\section{Test Matrix}

The test plates were tested at 5 Mach numbers: 0.35 , $0.4,0.5,0.6$, and 0.7 . The exhaust pressure used was $0.24 \mathrm{~atm}$. The micro-blowing flow rates for the test plates are listed in Table II.

\section{Results and Discussion}

To establish a baseline drag coefficient, two plain, stainless-steel, flat plates without holes were installed on both sides of the airfoil (Fig. 1) and were tested first. The total drag (pressure drag and skin-friction drag) coefficient, $C_{d o}$, was measured and was considered as a reference drag coefficient. The drag coefficients, $C_{d}$, were measured at the different Mach numbers for different porous test plates. The drag ratios, $C_{d w 0} / C_{d o}$, for unblown cases are shown in Fig. 6.

Only two plates ( LARC1 and GAC1897) out of the 12 plates had low drag ratios such that the drag reduction below a flat plate value was considered possible.

Before presenting more experiment results, the meaning of three slopes of a curve, as shown in Fig. 7, needs to be explained.

There are three possible slopes for a drag ratio curve as indicated in Fig. 7. Zero slope indicates that the rate of pressure-drag increase and the rate of skin-friction reduction are equal and that they cancel each other without a net total drag reduction. A positive slope implies that the rate of pressure-drag increase is larger than the rate of skin-friction reduction. A negative slope indicates that the rate of pressure-drag increase is less than the rate of skinfriction reduction and it shows a net total drag reduction. 
Because of the low unblown drag ratio, plates LARC1 and GAC 1897 were chosen for presenting the experiment results. The drag ratios for the LARC1 plate are shown in Fig. 8.

The drag ratio of 1.00 indicates that the drag of a porous plate is the same as that of a solid flat plate. In Fig. 8, the LARC1 plate did not go below 1.00 for all Mach numbers and blowing rates. The porosity (percent of open area) of the LARC1 plate is only 1.1 percent. The MBT was not effective for this extremely low-porosity plate and the drag reduction below a solid flat plate value was not achieved.

The other low unblown drag ratio was for the GAC1897 plate and the drag ratios of this plate are shown in Fig. 9.

The GAC1897 plate had slightly higher unblown drag ratios than those of the LARC1 plate, however, the MBT can reduce the total drag below a flat plate value for $\mathrm{Re} / \mathrm{m}$ of 1.96 and $2.26 \times 10^{6}$. Keep in mind that the total drag coefficient, $C_{d}$, includes the pressure drag and the skinfriction drag. Figure 9 shows that the GAC1897 plate did achieve a total drag reduction of 2.2 percent below a solid flat plate skin-friction value at a Mach number of 0.35 . Since the area of the blowing plates was about 50 percent of the total airfoil surface area and the skin-friction drag is about half of the total drag, the total drag reduction seen in Fig. 9 should be very small. The error of $C_{d}$ is about $\pm 1.4(10)^{-5}$.

For higher Reynolds numbers, this plate did not reduce the skin friction below a solid flat plate value (Fig. 9). This was caused by the limitation of the facility. The small test cross section of 14.22 by $20.32 \mathrm{~cm}$ and the airfoil cross section of 2.03 by $13.7 \mathrm{~cm}$ resulted in the model blockage of 9.6 percent. Besides, the higher skin friction of the wall and airfoil, and the addition of blowing air, made the boundary layer thicker inside the test section for high Reynolds numbers (Mach $=0.7$ ), and as a result, the static pressure at the wall was decreased as shown in Fig. 10. Consequently, the pressure on the rear half of the airfoil is lower than that of a free flight environment. Therefore, the pressure-drag penalty was overestimated and the total drag reduction was not achieved. It is believed that if the tests were conducted in a larger facility, the total drag reduction for higher Reynolds numbers could have been achieved.

In the phase I experiment, the NASA PN2 plate did achieve 25 percent more reduction in skin friction than GAC1897. However, because of the cost of the PN2, it was not tested in the phase II experiment. It would be possible to achieve higher total drag reduction if a more effective plate were tested.

\section{Suggestion for Finding an Optimal MBT Plate}

The best plate out of each group (Table I), such as a group of slotted holes, was selected and the drag coefficients were normalized with respect to the drag coefficient of the same porous plate without blowing, $C_{d w \sigma}$. The results show the effectiveness of micro-blowing for the different types of porous plates. The result is shown in Fig. 11 for the Mach number of 0.35. The GAC1897 plate had the lowest $C_{d} / C_{d w 0}$ value at the blowing fraction of 0.0025 . Therefore, the GAC1897 plate is considered the most effective plate of the 12 plates tested. It is very encouraging to see a clear trend of the total drag reduction for all porous plates that have ablowing fraction of less than 0.0025 . For the micro-blowing flow fraction less than 0.0025 , the skinfriction reduction outweighted the pressure-drag increase, and total drag reduction was achieved. However, when the blowing air exceeded 0.0025 , the total drag started to increase. Since all porous plates effectively reduce the total drag from the unblown drag for the micro-blowing flow rate $(F<$ 0.0025 ), the unblown drag is one of the most important parameters for finding an optimal MBT plate. Only the porous plate with the unblown drag not too much higher than the drag of a solid flat plate could reduce the drag below a solid flat plate value by using the MBT.

\section{Concluding Remarks}

The phase II experiment of the micro-blowing technique for reducing skin friction has been completed. The results showed that there existed a maximum microblowing flow rate below which the skin-friction reduction outweights the pressure-drag penalty, and total drag reduction was achieved. The pressure-drag penalty for a high-Reynolds-number flow was large caused by the blockage effect in the wind tunnel, and as a consequence, the total drag did not reduce below that of a solid flat plate value. Only one out of the 12 plates tested had an unblown total drag ratio so low that the reduction below a solid flat plate value was achieved after paying the penalty of the pressure-drag increase. More reduction in total drag could have been achieved if the PN2 plate (the best plate from the phase I test) had been tested. Several techniques to reduce the pressure-drag penalty have been proposed. One of the techniques, the combination of micro-blowing and micro-suction, will be tested in the near future. The search for an optimal MBT plate is continuing and a passive micro-blowing technique could be the final goal of this promising technique. 


\section{References}

1. Beltran, L.R.; Del Roso, R.L.; and Del Rosario, R.: Advanced Nozzle and Engine Components Test Facility. NASA TM-103684, 1992.

2. Hwang, D.P.: A Proof of Concept Experiment for Reducing Skin Friction By Using a Micro Blowing Technique. AIAA Paper 97-0546, 1997.
3. Cooper, G.K. and Sirbaugh, J.R.: PARC Code: Theory and Usage. Arnold Engineering Development Center Report AEDC-TR-89-15, Arnold AFS, TN, Dec. 1989.

4. Wilkinson, S.P.: Influence of Wall Permeability on Turbulent Boundary-Layer Properties. AIAA Paper 83-0294, 1983.

TABLE I.-SPECIFICATIONS OF TEST PLATES

\begin{tabular}{|c|c|c|c|c|c|}
\hline $\begin{array}{c}\text { Plate } \\
\text { number }\end{array}$ & Plate name & $\begin{array}{c}\text { Hole shape } \\
\text { side view/top view }\end{array}$ & $\begin{array}{c}\text { Hole size, } \\
\text { mm }\end{array}$ & $\begin{array}{c}\text { Thickness, } \\
\text { mm }\end{array}$ & Porosity \\
\hline 1 & Flate plate & N/A & N/A & 3.429 & N/A \\
\hline 2 & GAC1897 & hourglass/circle & 0.06 & 0.305 & 50 \\
\hline 3 & GAC2038 & conical/circle & 0.1 & 0.5 & 23 \\
\hline 4 & GAC2037 & conical/circle & 0.08 & 0.5 & 14 \\
\hline 5 & GAC2036 & conical/circle & 0.04 & 0.5 & 4 \\
\hline 6 & GAC2035' $^{1}$ & straight/slot & $0.04 \times 0.45$ & 0.5 & 20 \\
\hline 7 & GAC2035A $^{2}$ & straigtht/slot & $0.04 \times 0.45$ & 0.5 & 20 \\
\hline 8 & GAC2034' $^{\prime}$ & straight/slot & $0.02 \times 0.43$ & 0.5 & 10 \\
\hline 9 & GAC2034A $^{2}$ & straight/slot & $0.02 \times 0.43$ & 0.5 & 10 \\
\hline 10 & GAC2033' $^{1}$ & straight/slot & $0.01 \times 0.42$ & 0.5 & 5 \\
\hline 11 & GAC2033A & straight/slot & $0.01 \times 0.42$ & 0.5 & 5 \\
\hline 12 & Polyethylene & N/A & N/A & 6.35 & N/A \\
\hline 13 & LARC1 & straight/irregular & 0.076 & 0.635 & 1.1 \\
\hline
\end{tabular}

${ }^{1}$ Long slot edge perpendicular to flow direction.

'Long slot edge along flow direction.

TABLE II.-TEST MATRIX

\begin{tabular}{|l|c|c|c|c|c|}
\hline $\begin{array}{c}\text { Blowing flow rate } \\
\mathrm{kg} / \mathrm{sec} / \mathrm{m}^{2}\end{array}$ & \multicolumn{5}{|c|}{ Blow fraction } \\
\cline { 2 - 6 } & $\mathrm{M}=0.35$ & $\mathrm{M}=0.4$ & $\mathrm{M}=0.5$ & $\mathrm{M}=0.6$ & $\mathrm{M}=0.7$ \\
& $\mathrm{Re} / \mathrm{m}=1.96 \times 10^{6}$ & $2.26 \times 10^{6}$ & $2.87 \times 10^{6}$ & $3.52 \times 10^{6}$ & $4.23 \times 10^{6}$ \\
\hline 0 & 0.00000 & 0.00000 & 0.00000 & 0.00000 & 0.00000 \\
\hline 0.0212 & 0.00063 & 0.00055 & 0.00043 & 0.0035 & 0.00031 \\
\hline 0.0432 & 0.00126 & 0.00109 & 0.00087 & 0.00071 & 0.00060 \\
\hline 0.0864 & 0.00247 & 0.00216 & 0.00171 & 0.00142 & 0.00121 \\
\hline 0.1288 & 0.00368 & 0.00321 & 0.00258 & 0.00211 & 0.00181 \\
\hline 0.172 & 0.00489 & 0.00427 & 0.00344 & 0.00287 & 0.00240 \\
\hline 0.2152 & 0.00610 & 0.00533 & 0.00430 & 0.00357 & 0.00300 \\
\hline & & & & & \\
\hline
\end{tabular}




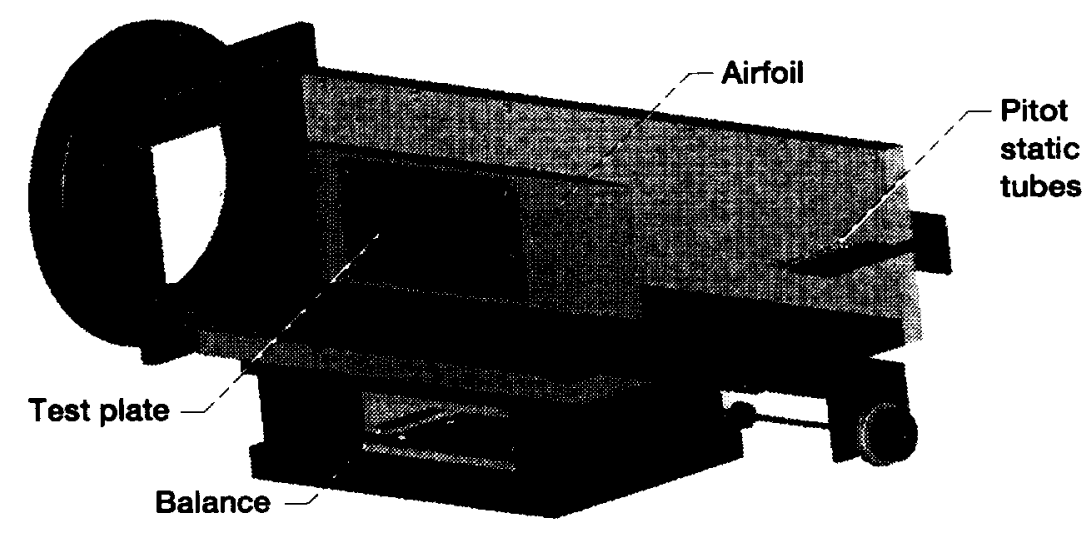

Figure 1.-Test model.

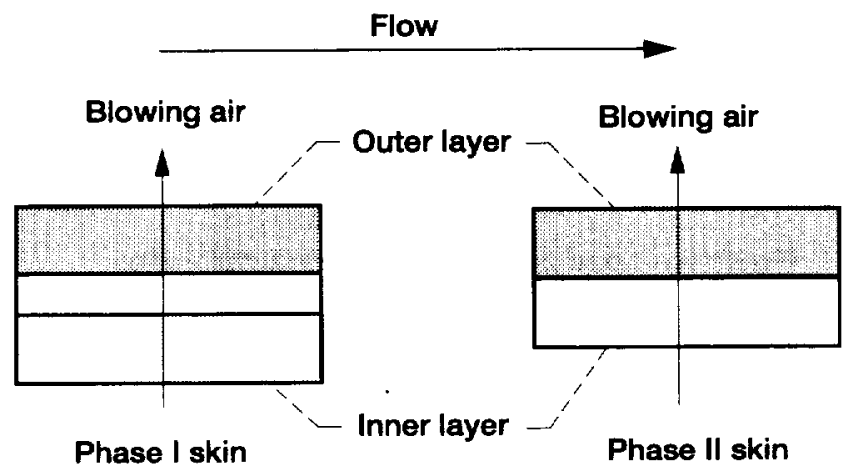

Figure 2.-Phase I and phase II plates.

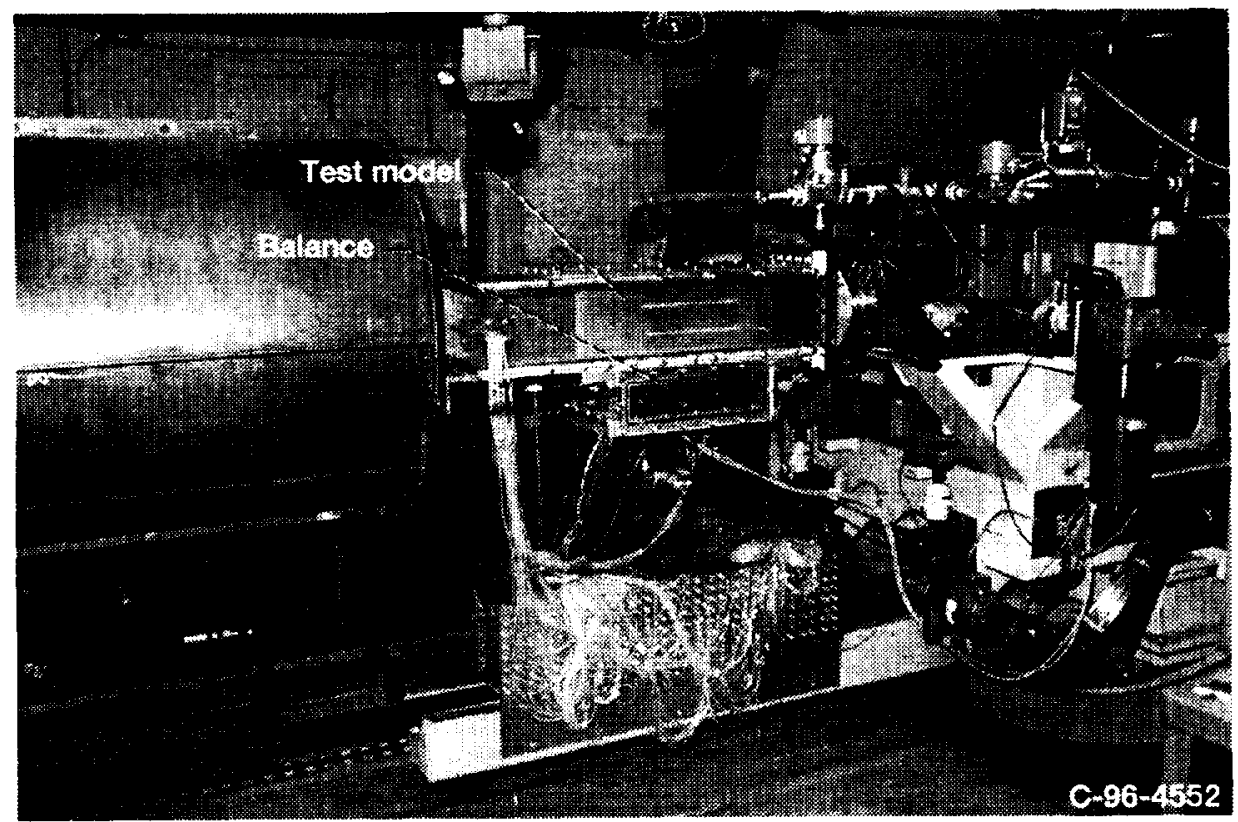

Figure 3.-Experiment setup. 


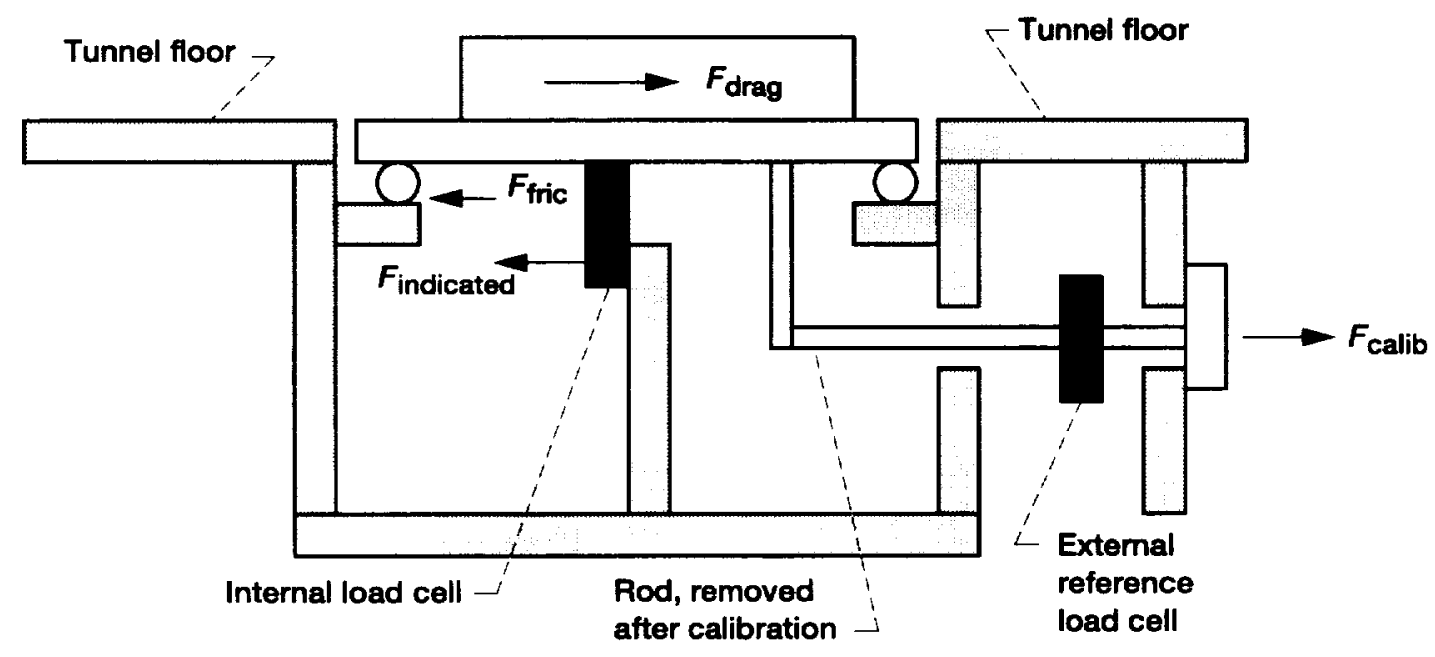

Figure 4.- Load cell locations during calibration.

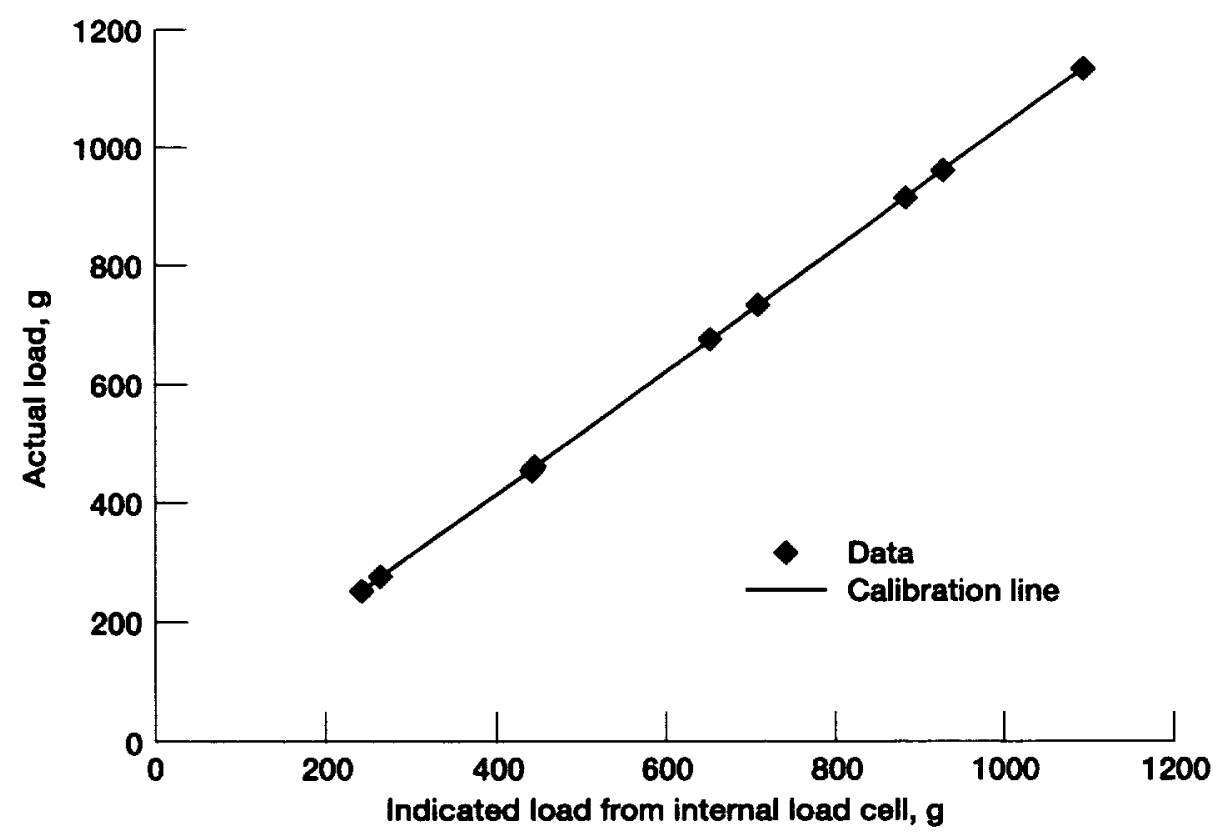

Figure 5.-Calibration line. 


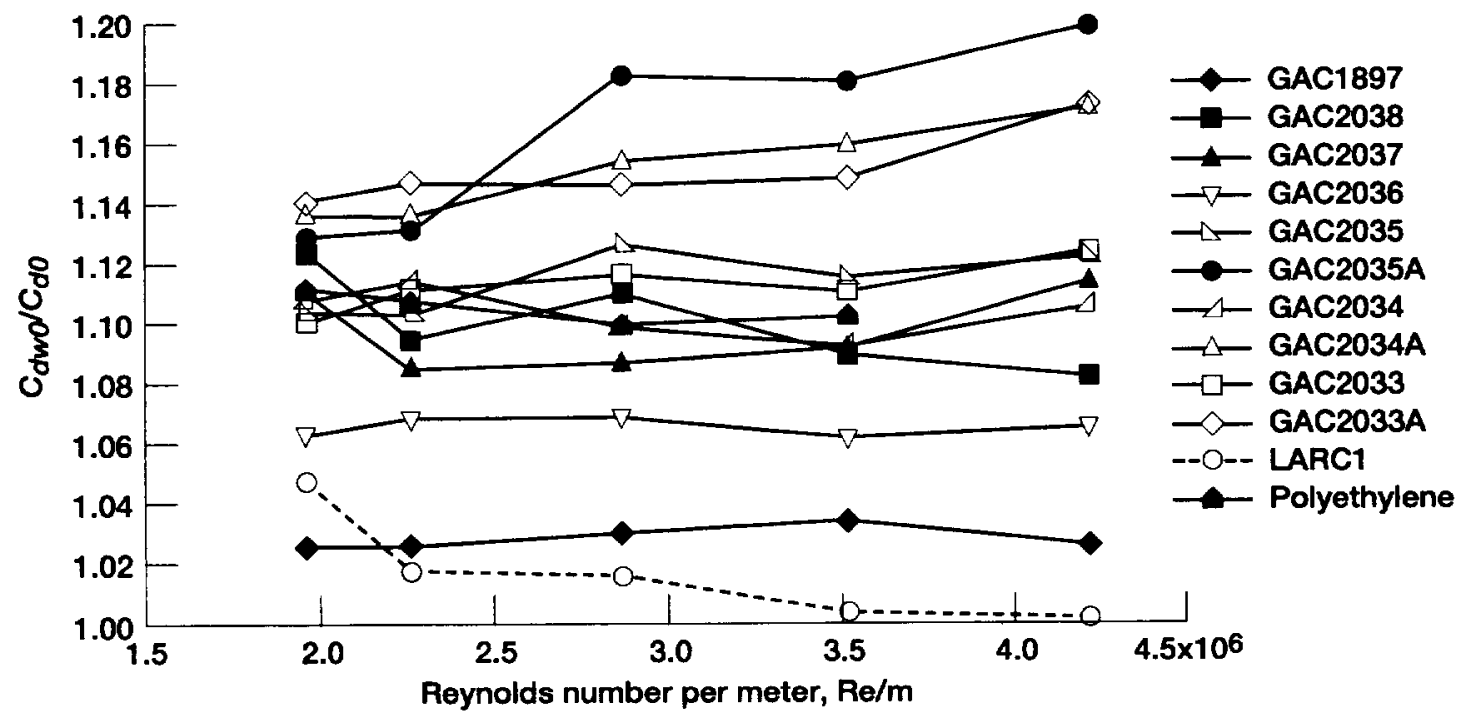

Figure 6.-Unblown drag ratios.

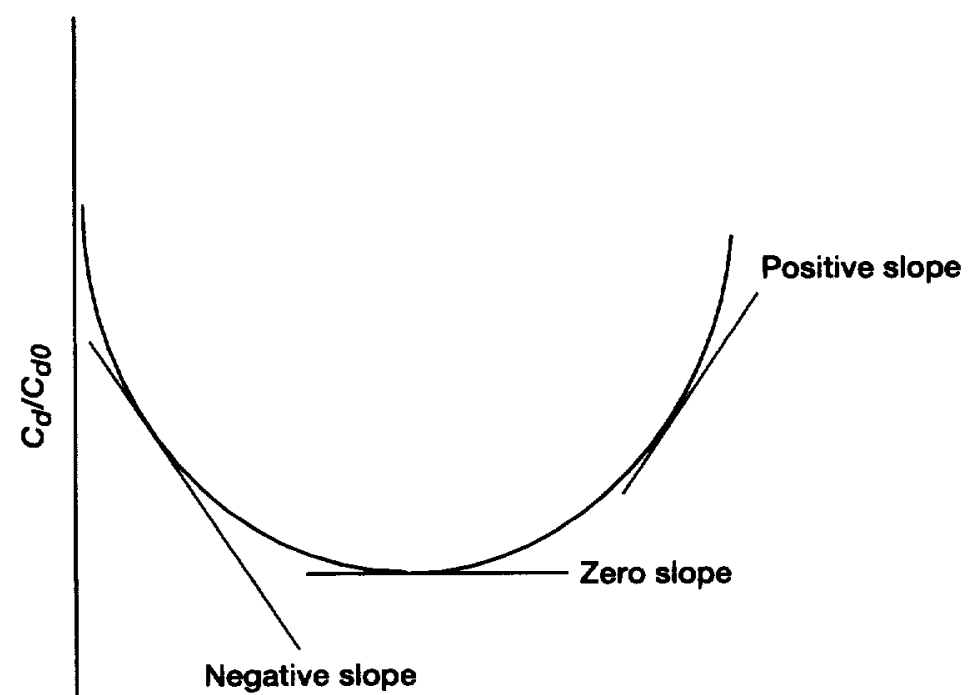

Blowing rate

Figure 7.-Three slopes. 


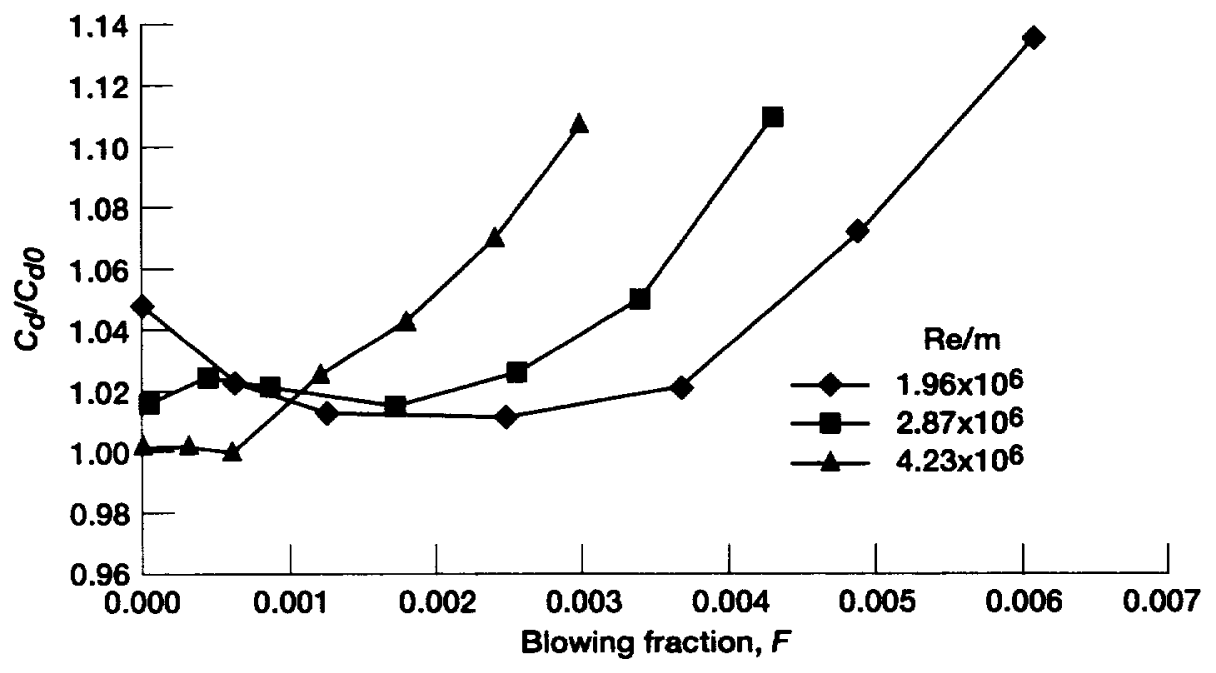

Figure 8.-Drag ratio of LARC1.

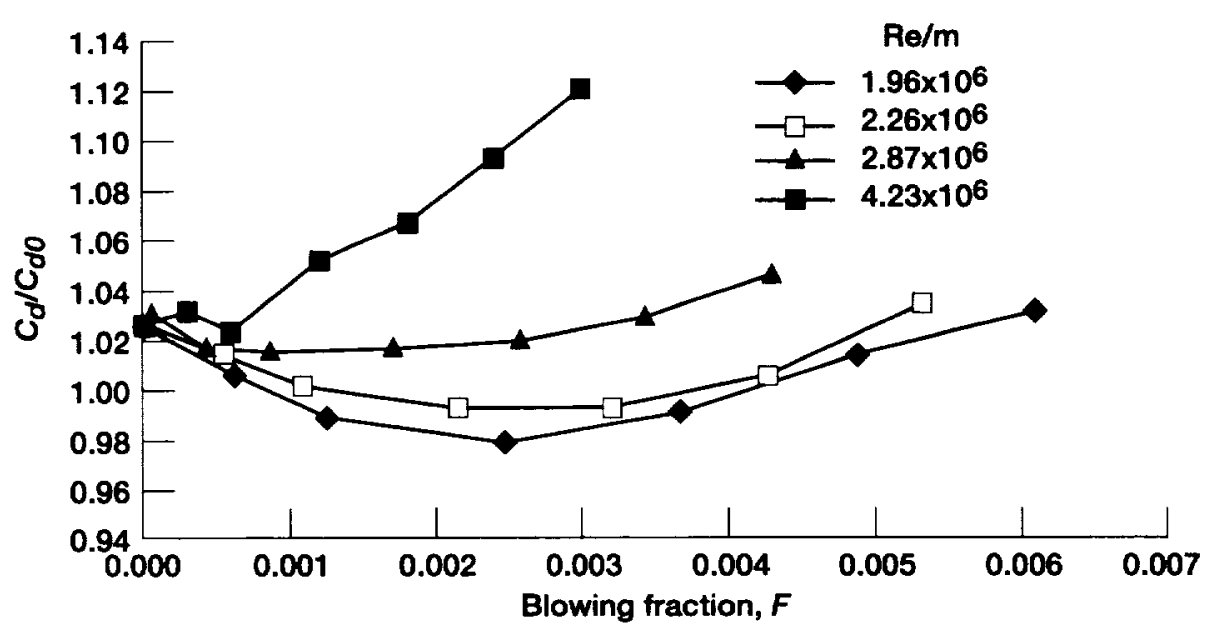

Figure 9.-Drag ratio of GAC1897. 


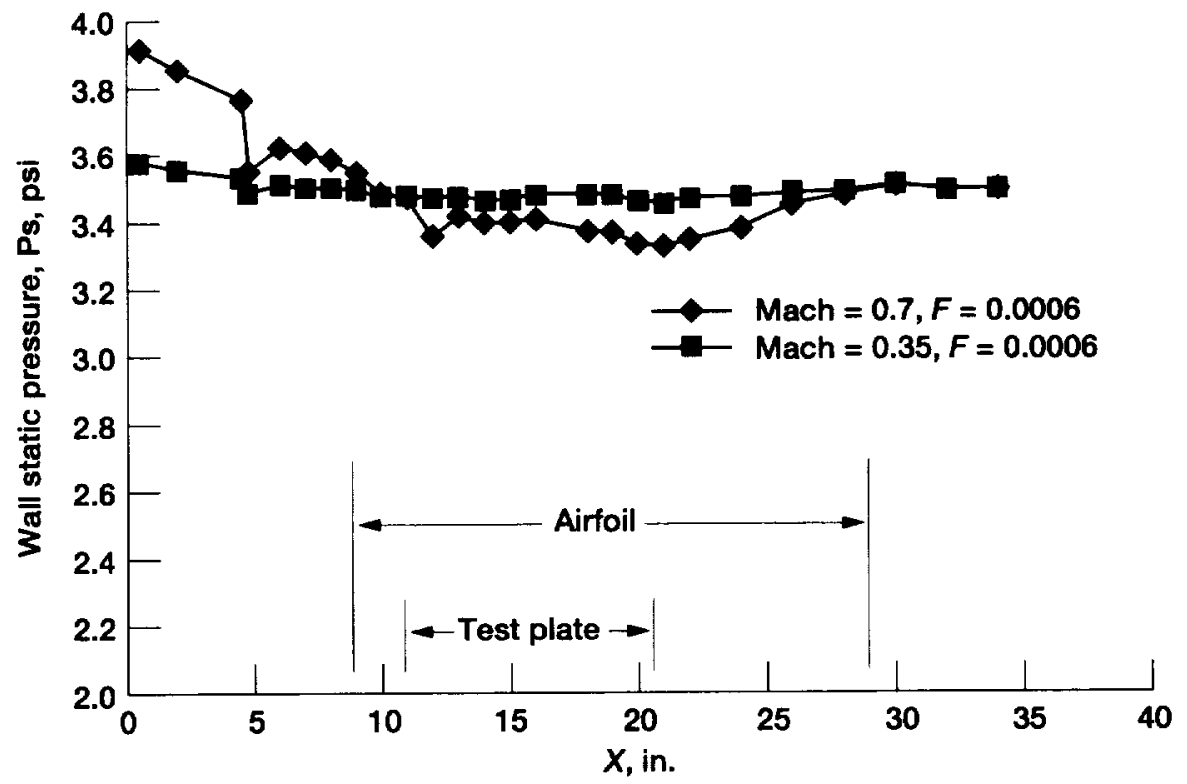

Figure 10.-Wall static pressure.

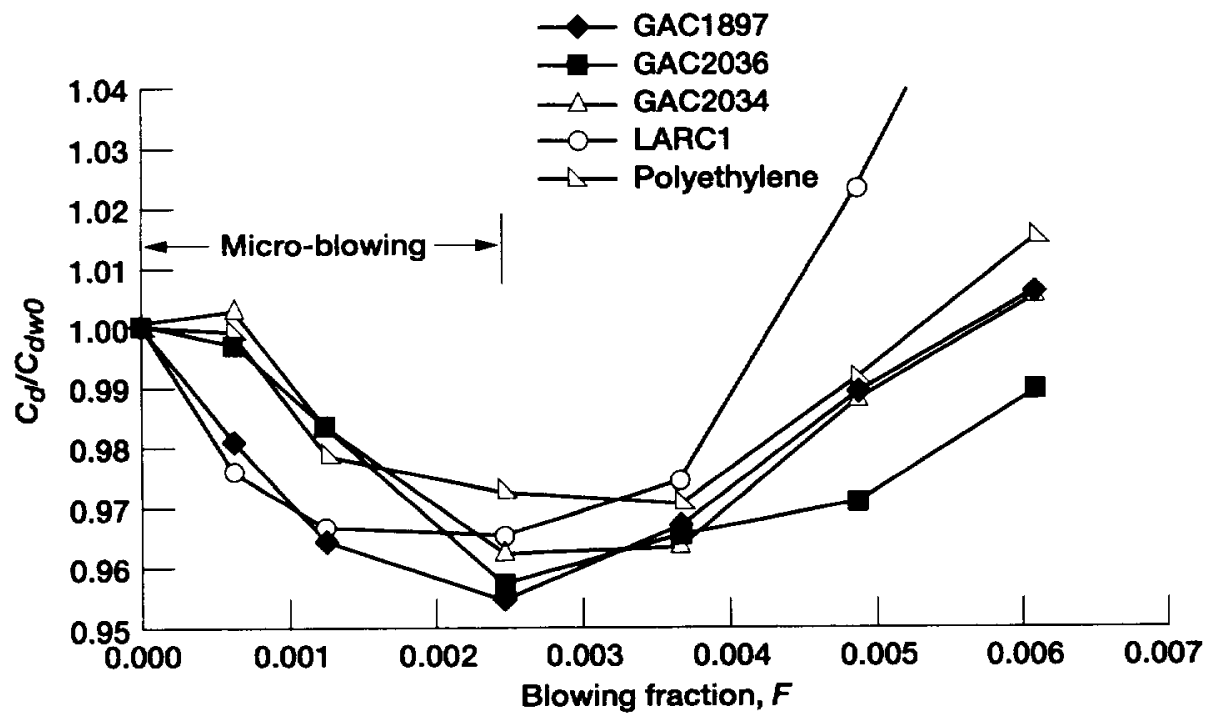

Figure 11. Micro-blowing effectiveness, Mach number $=0.35$. 


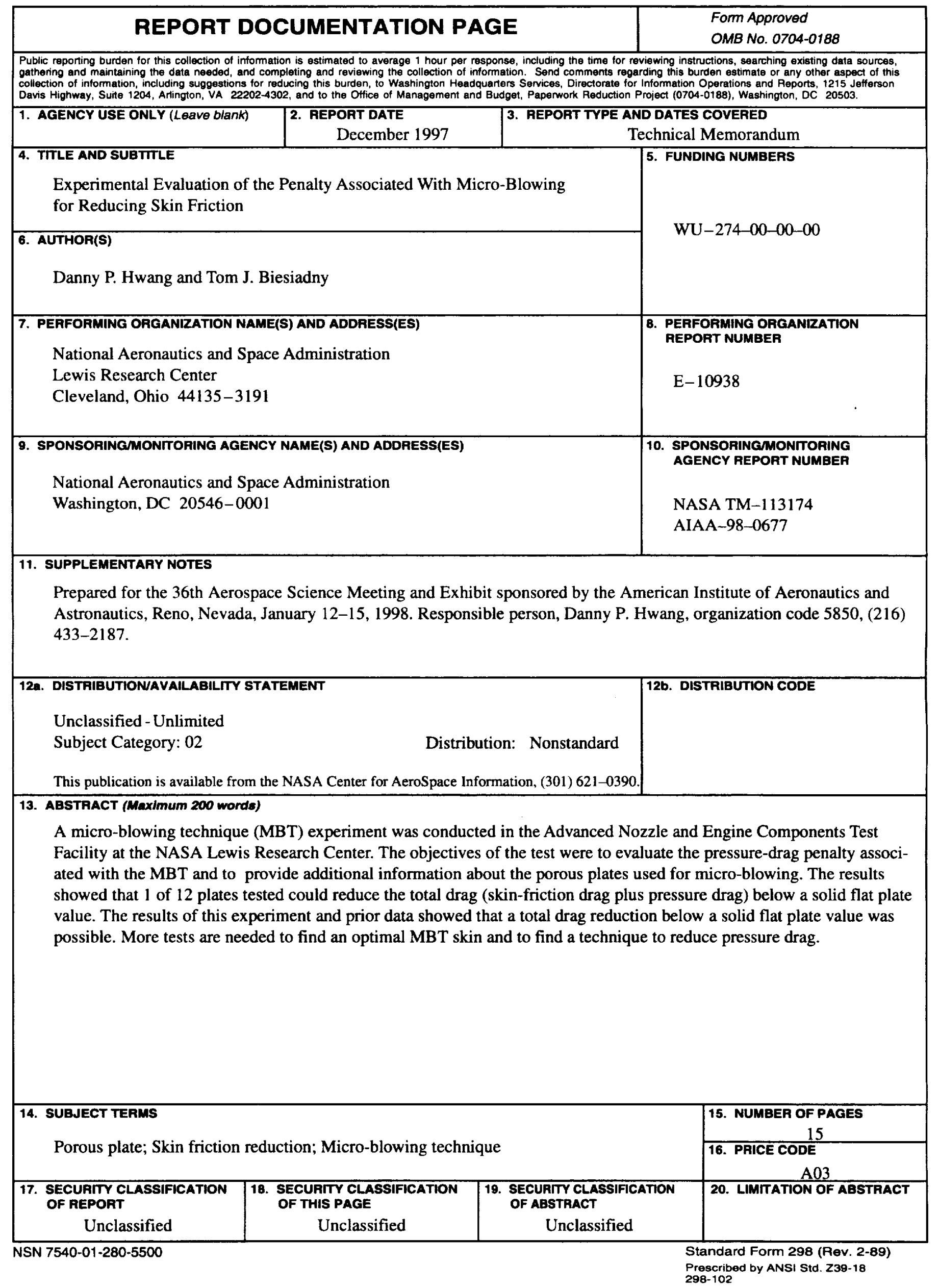

